\title{
Development of Entrepreneurship E-Module for Elementary School Students Based on Local Wisdom in Madura Island
}

\author{
Indah Setyo Wardhani ${ }^{a}{ }^{*}$, Rika Mellyaning Khoiriya ${ }^{a}$ \\ ${ }^{a}$ University of Trunojoyo Madura Bangkalan, Indonesia \\ *E-mail: setyowardhani@yahoo.co.id
}

\begin{abstract}
The aim of this research is to develop a valid, practical and effective entrepreneurship e-module for Elementary School students in Madura. The validity level of the entrepreneurship e-module is known through the results of validation analysis by the validator. The level of practicality is known through observations of the use of entrepreneurship e-module, and the level of effectiveness known from two aspects, namely (1) the average score of students' learning outcomes and (2) positive responses of the students. The development research model used to modify the 4D model by Thiagarajan and Sammel that consists of four stages, namely the stages of defining, designing, developing, and disseminating
\end{abstract}

\section{Introduction}

Indonesia is the largest archipelago country in the world in the Southeast Asia with an area of $1,904,569 \mathrm{~km}^{2}$ and 17,508 islands. According to the data from Home Affairs Ministry of Republic of Indonesia in 2004 there are 17,508 existing islands, 7,870 of them have names, while 9,634 islands do not have names. Among the islands that have names, there were islands that were inhabited and uninhabited. Among inhabited areas, there are various natural and cultural diversities that characterize the uniqueness of each region so that they can distinguish one region from another. The diversity of nature and culture in the form of cultural diversity, ethnicity, customs, beliefs that all make Indonesia becomes rich, remain united, peaceful, and promote unity in diversity which means different but still one. The diversity of nature and culture in Indonesia influences the habits, ethics, and behavior of Indonesian people to make Indonesia becomes that rich country of local wisdom.

Madura is one of the islands in Indonesia which is located at coordinates $7^{\circ} 0^{\prime} \mathrm{S} 113^{\circ} 20^{\prime} \mathrm{E}$ and an area of 5,168 $\mathrm{km}^{2}$ with a population almost 4 million people. There are 127 islands in Madura, with the largest islands being the Kangean Archipelago and the Masalembu Archipelago. Madura Island consists of four districts namely Bangkalan, Sampang, Pamekasan, Sumenep districts, each of which has its own uniqueness. Madura Island has a lot of potentials in the tourism aspects, natural resources, and cultures. The field of tourism includes historical tourism, natural tourism, religious 
tourism and cultural tourism, while natural resources in Madura include corn, salt and fish. Seeing those abundant potentials, Madura is called a hidden paradise.

Madura Island is rich of local wisdom. One of the local wisdom that is hereditary is the entrepreneurial spirit. Madurese are able to create valuable things for themselves and others and are known as hardworking souls. Since childhood, Madurese have been accustomed to working in terms of earning money. For the Madurese community, supporting themselves is an absolute obligation. Even for most of the 80s and below, many children and school days were sacrificed to work. Whether it is working to help parents, or make a living on their own. Unfortunately this hardworking mentality has begun to erode from the next generation. Moreover, the generation of the 90s and next generations, considered the work of farming a heavy work does not produce. Even so, the Madurese of the 90s and beyond preferred smart work. Spending as little energy and capital as possible, to get the maximum income possible. Because this generation of education is different, Madurese of the 90s and above have started to be technology literate. Moreover, they have received good education, at least junior high school. Although they are both educated not to be spoiled, they still have a different perspective on working for a living. However, the Madurese are still hardworking figures. There are no Madurese who are truly unemployed. They at least still have activities that make money even though they are impermanent. Whether from helping both parents and working odd jobs.

The phenomenon of life in Madura must be balanced with technological development. It is important to realize that Indonesian society has recently been faced with the Industrial Revolution 4.0. Facing the challenges of the rapid growing industrial revolution, the world of education, especially the primary education and middle education are demanded to immediately improve. The era of education influenced by the industrial revolution 4.0 is education characterized by the use of digital technology in the learning process or better known as the cyber system. This system is able to carry out the learning process continuously with not limited to space and time. Teachers who are at the forefront in the world of education must upgrade their competence in the face of the industrial revolution, where students facing teachers today are millennial students who are familiar with the digital world and are familiar with the flow of information and industrial technology. This shows that products from the world of education must be able to answer the challenges of industry 4.0.

The 4.0 industrial revolution is currently recognized by the presence of four things, namely super computers, artificial intelligence, cyber systems, and manufacturing collaboration. It requires competencies, especially teachers as the front guard in the world of education that is able to balance the presence of these four things. The required competence is one of the projected competency requirements towards the 5.0 revolution. The first competence is critical thinking skills and problem. Second competence is communication and collaborative skills. Third competence is creative thinking and innovation skills. Fourth competence is information and communication technology 
literacy. Fifth competence is contextual learning skills. Sixth competence is information and media literacy. Entering the industrial revolution 4.0, the existence and role of teachers becomes very important in order to be literate in digital literacy. Digital literacy is not just about computer subjects, but on all subjects already using technology in the daily lives of students. The role of the teacher is not replaced by technological progress, only if he is negligent in the use of technology, does not act creatively, and is innovative, then the teacher can be replaced by technology. Teachers besides digital literacy are also able to position themselves as motivators and inspirators. Millennial students no longer read printed books but have used digital in their daily lives. More importantly, students should not only be facilitated by tablets or computers, but the values or values of soft skills, empathy, collaboration and love for the underlying local wisdom going forward. Those values must be instilled in students, so as to produce graduates with local knowledge

According to Rahyono (2009: 7), local wisdom is a human intelligence possessed by certain regional groups that is obtained through community experience. In this sense, local wisdom can be interpreted as the creation of a group of people, through their experience and not necessarily experienced by another group of people. The values that are embedded from local wisdom can be attached to a group of people later will be a noble value as long as the community's existence. These noble values are generally in the form of long experiences, which are inseparable from the environment, and are dynamic, open, flexible, and adapt to their times. Local wisdom is the identity or cultural personality of a nation that causes the nation to be able to absorb, even cultivate cultures that come from outside / other nations into own character and abilities (Wibowo, 2015: 17). Forms of local wisdom include culture (values, norms, ethics, beliefs, customs, customary law, and special rules). Noble values related to local wisdom include love for God, responsibility, discipline, and independence, honesty, respect and courtesy, compassion and care, confidence, creativity, hard work, and never give up, justice and leadership, kind and humble, tolerance, peace, and unity.

Local wisdom is a part of the culture of a society that cannot be separated from the community itself. Local wisdom is generally passed down from generation to generation. Local wisdom is in folklore, proverbs, songs, natural products, and folk games. Local wisdom as a knowledge found by certain local communities through a collection of experiences in trying and integrated with an understanding of the culture and natural conditions of a place. Challenges for the education in the future where is necessary to control the use of technology that remains oriented to local wisdom. Educational products are needed that can facilitate students in facing the industrial revolution 4.0 and remain based on local wisdom.

It is important to teach an entrepreneurial spirit from an early age. Entrepreneurship Education aims to develop attitude, spirit and the ability to create valuable things for oneself and others. Creative, innovative, independent, leadership, good at managing money, and having a spirit are 
some of the entrepreneurial attitudes that need to be instilled in children from an early age. This needs to be instilled early on considering the various economic challenges facing the greater Indonesian State. These entrepreneurial values become important points in the formation of life skills in children. Besides through education in the family, entrepreneurship education can be implemented in an integrated manner with learning activities in schools. Elementary School students can be trained to develop attitudes, souls and entrepreneurial abilities through a variety of creative activities that can be integrated with the applicable curriculum. Teachers can use various strategies and methods to foster good values from the character of successful entrepreneurs. Entrepreneurship education taught since elementary school is expected to reduce the consumption patterns of children by training to create something of value and bringing the next generation to create jobs in the future. In this case, teachers and parents have an important role to develop children's life skills and foster interest and potential in children through entrepreneurship. The strategy to put the spirit of hard workers starts early for the Madurese community through the development of entrepreneurship emodules for elementary school students based on local wisdom for elementary school children.

\section{Research and Development Procedures}

This development research model modifies the 4D model by Thiagarajan and Sammel (Hobri, 2010: 8). The reason for using this model is because it is developed neatly, and the development procedures are arranged systematically through four stages, namely the stages define, design, develop, and desseminate. The development procedure is the steps taken to make a product. This development research procedure modifies the 4D model with some adjustments. This development research procedure consists of the stages of definition, design, development. Desseminate is limited to schools which are used as research subjects. The description of each stage is as follows.

\section{A. Defining Phase}

- Analyzing the aims and limits of the material.

- Identify the characteristics of elementary school students in Madura

- Arrange systematically the concepts and tasks to be taught based on a preliminary analysis.

\section{B. Design Stage}

- Determine competency standards, basic competencies, and entrepreneurial learning goals.

- Determine the stages of material on the entrepreneurship e-module

- Determine the e-module design

- Determine studies of local potential namely food 


\section{Development Stage}

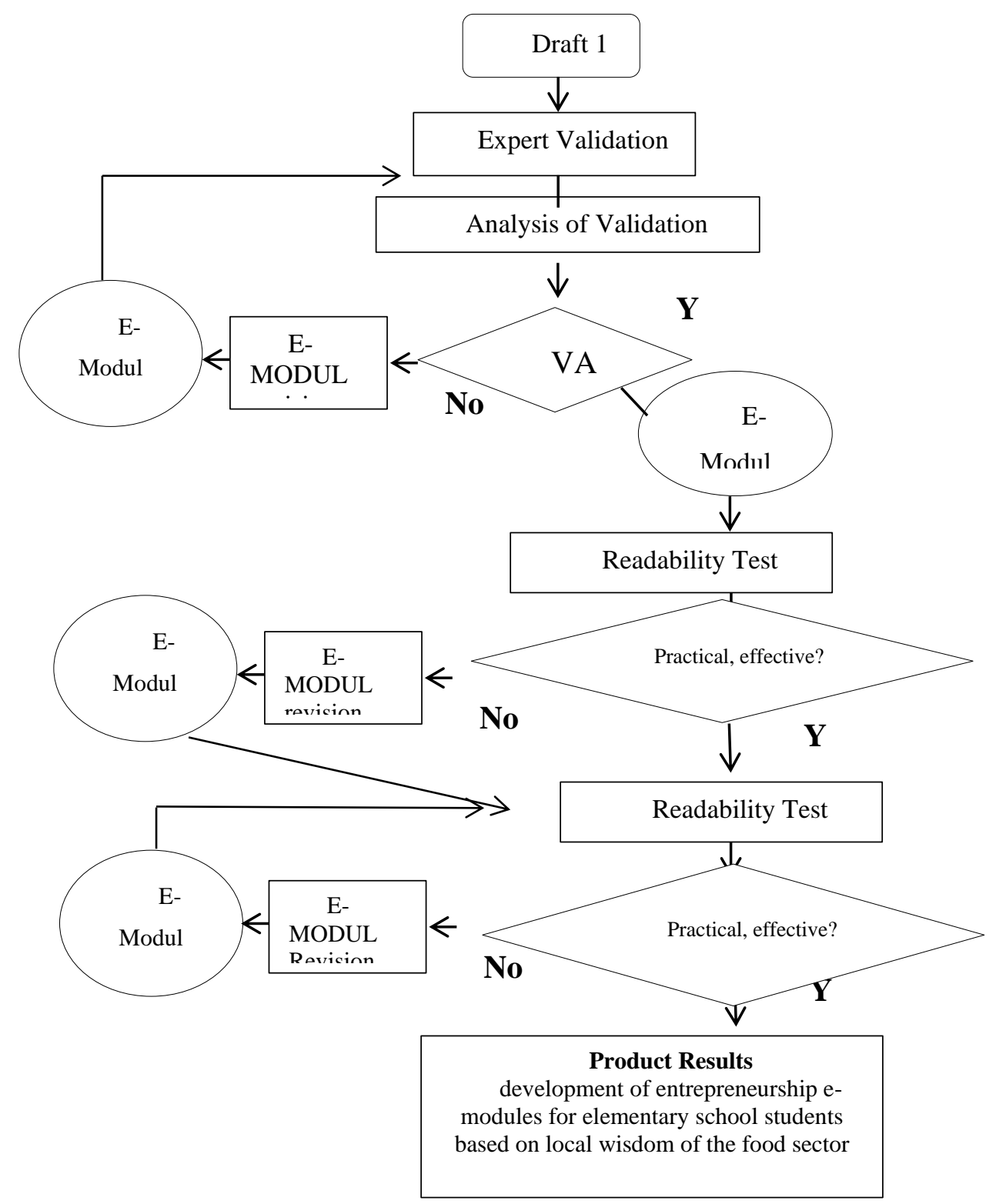

Figure 1. Modification of the 4D Research \& Development Model

\section{Try-out}

\section{A. Try-out Design}

A trial was conducted to see the validity, effectiveness and practicality of the entrepreneurship e-module that was created. The validity aspect was known through the results of the analysis of validation activities by two validators. The practicality aspect is known by observing the results of the use of the entrepreneurship e-module. The effectiveness aspect of the entrepreneurship e-module can be seen from two things, namely (1) the average score of students' learning achievement test results obtained by the test subjects is more than or equal to the Minimum Learning Standards that have been set and (2) positive student responses. 


\section{B. Try-out Subject}

The subjects of the trial were material experts, learning design experts and fifth grade students of SDN Banyuajuh Kamal Madura and SDN Demangan 1 Bangkalan Madura. The sampling technique was purposive sampling, with consideration that the two elementary schools had the same academic level characteristics in different place.

\section{Data Type}

The type of data obtained is divided into two, namely qualitative data and quantitative data. Qualitative data in the form of input, responses and suggestions for improvement based on the results of expert research obtained through validation and questionnaires. Quantitative data in the form of assessment scores provided by the validator, student responses, observations, and student mastery in working on the test results of learning after mastering the use of modules.

\section{Data Collection Instruments}

The instrument is used to collect data to be analyzed so that the results illustrate that the developed entrepreneurship e-module is good or not.

Table 1.

Aspects, Instruments, Observed Data, and Respondents

\begin{tabular}{llll}
\hline Assessed Aspect & Instrument & Observed Data & Respondent \\
\hline Validity & Validation & Validity of & Material Expert and \\
entrepreneurship e-module & Sheet & entrepreneurship e-module & learning design expert \\
\hline Practicality & Observation & Implementation & Observer \\
entrepreneurship e-module & Sheet & entrepreneurship e-module & teacher) \\
\hline entrepreneurship e-module & Questionnaire & Students' Responses & Test Subject \\
\cline { 2 - 4 } & Test & learning outcomes & Test Subject \\
\hline
\end{tabular}

\section{E. Appendices}

Analysis of the data used in this research is descriptive qualitative analysis and descriptive statistics.

a) Qualitative Descriptive Analysis. Qualitative descriptive data analysis is used to process data in the form of notes, suggestions, or comments based on the results of the assessment contained in the validation sheet, observation sheet and questionnaire.

b) Descriptive Statistics Analysis. Descriptive statistical analysis used to analyze data in the form of scores from the results of validation, observation, questionnaire responses of students, learning outcomes tests. Validity Analysis seen from the results of the validation of the subject matter experts and evaluation of learning about the development of instruments developed Practical Analysis seen from the observation of the implementation of the use of entrepreneurship e-modules for elementary school students based on local wisdom of the food sector 
Analysis of effectiveness data measures how far the level of effectiveness of the entrepreneurship e-module for elementary school students based on local wisdom in the food sector is tested in the classroom. Indicators of effectiveness of learning tools are analyzed as follows.

- Analysis of Student Learning Outcomes Data. The average score obtained by students after completing the entrepreneurship e-module test for elementary school students based on local wisdom of the food sector is $\geq 70$. In addition the module is said to be effective if $65 \%$ of all students get a score of $\geq 70$.

- Analysis of student response data. The response of students who were asked at the end of the trial run to (a) the attractiveness of the picture illustrations in the e-module, (b) the language used.

\section{Findings}

The development of the entrepreneurship e-module for elementary school students based on local wisdom of the food sector was carried out at the Elementary School in Bangkalan, Madura. Madura's local wisdom was observed in batik, culinary, carving entrepreneurs, etc. in Bangkalan, Sampang, Sumenep and Pamekasan areas. Module validation is carried out by material experts and media design experts. The try-out was conducted at two elementary schools in Bangkalan. It was conducted in $5^{\text {th }}$ class with a total of 50 students.

\section{A. Description of Expert Validation}

Expert validation on the product of entrepreneurship module consisted of material and media expert validation. Material expert was conducted on the content, material, and integration aspects. Meanwhile, media expert was carried out on the presentation and graphic aspects.

a. The results of material expert validation. The results of material expert could be presented in table 5.1 as follows.

Table 2.

Overall Material Expert Test Results

\begin{tabular}{l|cc}
\hline \multicolumn{1}{c|}{ Assessment Aspects } & Total score & Average Score \\
\hline Content / material & 33 & 3,33 \\
Linguistic & 32 & 3,56 \\
Cohesiveness & 33 & 3,66 \\
Total score & $\mathbf{9 8}$ & 10,55 \\
Mean & $\mathbf{3 2 , 6 6}$ & $\mathbf{3 , 5 1}$ \\
\hline
\end{tabular}

Source: processed primary data

Table 2 above showed that the overall material expert validation results obtained a score of 99 and the average number of scores for each aspect was 3.51. The breakdown of the total score includes the aspect of content / material obtained a total score of 33 with an average score of 3.33; 
linguistic aspects obtained a total score of 32 and an average score of 3.56; and the cohesiveness aspect obtained a total score of 33 and an average score of 3.66 .

b. Test results of media design experts. The results of the media design expert validation could be presented in table 3 as follows.

Table 3.

Data of Design and Media Experts Validation

\begin{tabular}{l|lll}
\hline No. & Assessment Aspects & Score & Average Score \\
\hline 1 & Presentation & 24 & 3,25 \\
2 & Graphic / Appearance & 26 & 2,7 \\
Total score & 50 & 5,95 \\
Average & 25 & $\mathbf{2 , 9 8}$ \\
\hline
\end{tabular}

Source: processed primary data

Table 3. above shows that the results of the overall media design expert test obtained an overall score of 50 with an average score of each indicator for the presentation of 3.35 and the graphic / display aspect gained a score of 26 with an average score of 2.7 .

\section{B. Description of Test Data on the Use of Entrepreneurship Modules by Students}

The try-out data on the use of entrepreneurship modules by the students consisted of 3 aspects namely material / content, linguistic, and functional aspects. Test the use of modules in learning by students was done in $5^{\text {th }}$ class students with a total of 50 students. The results of module usage by students could be seen in table 5.3 as follows:

Table 4.

Data of Student Readability Test

\begin{tabular}{l|cc}
\hline Assessment aspects & Total score & Average score \\
\hline Material / Content & 16,75 & 4,15 \\
Language & 16,88 & 4,24 \\
Function & 17,56 & 4,23 \\
Total score & $\mathbf{5 1 , 1 9}$ & $\mathbf{1 2 , 6 2}$ \\
Average & $\mathbf{1 7 , 0 6}$ & $\mathbf{4 , 2 1}$ \\
\hline
\end{tabular}

Source: processed primary data

Table 5.3. above showed that the results of try-out on the use of entrepreneurship modules by students obtained a total score of 51.8 with an average score of 17.66 for each aspect and an average total score of 12.62 with an average score of 4.21 for each aspect. Material aspects got a score of 16.75 with an average of 4.15. The language aspect got a score of 16.88 with an average of 4.24. The functional aspect gained a score of 17.56 with an average of 4.23.

\section{Conclusion}

- Based on the results and outcomes achieved, it could be concluded that the results of the validation of material and media design experts on Madura Local Wisdom-Based Entrepreneurship 
E-Module and Print out module in Elementary Schools were effectively and efficiently used. Besides the implementation of learning in filling the spirit of entrepreneurship in elementary students got good results and. Therefore, this development research needs to be followed up to the product dissemination stage in the Madura region so that the cultivation of entrepreneur spirit begins early on through local wisdom-based entrepreneurship education

\section{Acknowledgments}

We would like to thank the entrepreneur in Madura Island, UPTD SDN Banyuajuh 2 and UPTD Banyuajuh 4 who have been conducted to do research development about Entrepreneurship EModule for Elementary School Students Based on Local Wisdom in Madura Island.

\section{References}

[1] Arikunto, S. 2006. Prosedur Penelitian, Suatu Pendekatan Praktik. Jakarta:Rineka Cipta.

[2] Armstrong, Thomas. (2006). The Best School (Mendidik Siswa Menjadi Insan Cendekia Seutuhnya). Bandung:PT Mizan Pustaka.

[3] Budiyarti, Sri. (2014). Problematika Pembelajaran di Sekolah Dasar. Yogyakarta:Deepublish.

[4] Ciputra. (2009). Ciputra Quantum Leap (Entrepreneurship Mengubah Masa Depan Bangsa dan Masa Depan Anda). Jakarta:PT Elex Media Komputindo.

[5] Hobri. 2010. Metodologi Penelitian Pengembangan (Aplikasi Pada Penelitian Pendidikan Matematika). Jember:Pena Salsabila.

[6] Novita, Windya. (2007). Serba Serbi Anak. Jakarta:PT Elex Media Komputindo.

[7] Sangkanparan, Hartono. (2012). Mencetak Superman Masa Depan. Jakarta:Visi Media

[8] Suharyadi, dkk. (2007). Kewirausahaan Membangun usaha Sukses Sejak usia Muda. Jakarta:Salemba Empat

[9] Suparyanto. (2013). Kewirausahaan (Konsep dan Realita pada Usaha kecil). Bandung:Alfabeta.

[10] Rahyono, F.X. 2009. Kearifan Budaya Dalam Kata. Jakarta: Wedatama Widya Sastra

[11] Tridhonanto, Al. (2015). Jangan Katakan Bodoh! (Buku panduan bagi Orang Tua dan Guru). Jakarta:Bisakimia.

[12] Wardhana, Dony S. (2013). 100\% Anti Nganggur (Cara Cerdas Menjadi Karyawan atau Wirausahawan). Bandung:Ruang Kata.

[13] Wibowo, Agus. 2015. Pendidikan Karakter Berbasis Kearifan Lokal di Sekolah. Pustaka Pelajar: Yogyakarta

[14] Wibowo, Budhi dan Adi Kusrianto. (2010). Menembus Pasar Ekspor, Siapa takut. Jakarta:PT Elex Media Komputindo.

[15] Wijatno, Serian. (2009). Pengantar Entrepreneurship. Jakarta:Grasindo. 